\title{
Colistin-resistant Escherichia coli carrying mcr-1 in food, water, hand rinse, and healthy human gut in Bangladesh
}

\author{
Fatema-Tuz Johura', Jarin Tasnim', Indrajeet Barman', Sahitya Ranjan Biswas' ${ }^{1}$ Fatema Tuz Jubyda1, \\ Marzia Sultana', Christine Marie George ${ }^{2}$, Andrew Camilli³ ${ }^{3}$ Kimberley D. Seed ${ }^{4}$, Niyaz Ahmed ${ }^{1}$ \\ and Munirul Alam ${ }^{1 *}$ (D)
}

\begin{abstract}
Background: One of the most significant public health concerns in today's world is the persistent upsurge of infections caused by multidrug resistant bacteria. As a result, clinicians are being forced to intervene with either less effective backup drugs or ones with substantial side-effects. Colistin is a last resort antimicrobial agent for the treatment of infections caused by multi-drug resistant gram-negative bacteria.

Methods: Escherichia coli $(n=65)$ isolated from street food $(n=20)$, hand rinse $(n=15)$, surface water $(n=10)$, and healthy human stool $(n=20)$ were tested for colistin resistance gene $m c r-1$ and response to antimicrobial agents. Antimicrobial resistance genes and virulence genes were detected by employing polymerase chain reaction. DNA fingerprinting of the strains were determined by pulsed-field gel electrophoresis.

Results: Screening of E. coli allowed us to confirm colistin resistance marker gene mcr-1 in 13 strains (street food, $\mathrm{n}=4$; hand rinse, $\mathrm{n}=2$; surface water, $\mathrm{n}=4$; and stool, $\mathrm{n}=3$ ); and two of these $E$. coli strains carrying $m c r-1$ harbored bla $a_{\text {TEM }}$ gene encoding extended spectrum beta lactamase. Antibiotic assay results revealed all 13 E. coli strains carrying $m c r-1$ to be multi-drug resistant (MDR), including to colistin. The minimum inhibitory concentration (MIC) for colistin ranged from 2 to $6 \mu \mathrm{g} / \mathrm{ml}$. DNA sequencing confirmed homogeneity of the nucleotide sequence for $m c r-1$, but the $E$. coli strains were heterogenous, as confirmed by pulsed-field gel electrophoresis suggesting horizontal transmission of colistin resistance in Bangladesh.
\end{abstract}

Conclusion: Widespread dissemination of E. coli strains carrying mcr-1 encoding resistance to colistin in the present study is alarming as this is the last resort drug for the treatment of infections caused by MDR gram-negative bacteria resistant to almost all drugs used commonly.

Keywords: Colistin, mcr-1, ESBL, Multi-drug resistant (MDR), Minimum inhibitory concentration (MIC), Horizontal transmission

\footnotetext{
*Correspondence: munirul@icddrb.org

1 Infectious Diseases Division (IDD), International Centre for Diarrheal

Disease Research (icddr,b), 68, Shaheed Tajuddin Ahmed Sharani, Dhaka 1212, Bangladesh

Full list of author information is available at the end of the article
}

\section{Background}

Antimicrobial resistance (AMR) is one of the major global public health concerns of this century, which has made the effective treatment of an ever-increasing array of infectious diseases very challenging. The overuse of antibiotics in health and agriculture has put ubiquitous microbes under consistent selective pressure. As a

(c) The Author(s) 2020. This article is licensed under a Creative Commons Attribution 4.0 International License, which permits use, sharing, adaptation, distribution and reproduction in any medium or format, as long as you give appropriate credit to the original author(s) and the source, provide a link to the Creative Commons licence, and indicate if changes were made. The images or other third party material in this article are included in the article's Creative Commons licence, unless indicated otherwise in a credit line to the material. If material is not included in the article's Creative Commons licence and your intended use is not permitted by statutory regulation or exceeds the permitted use, you will need to obtain permission directly from the copyright holder. To view a copy of this licence, visit http://creativeco mmons.org/licenses/by/4.0/. The Creative Commons Public Domain Dedication waiver (http://creativecommons.org/publicdomain/ zero/1.0/) applies to the data made available in this article, unless otherwise stated in a credit line to the data. 
result, only the microbes resistant to multiple antibiotics are thriving in the environment [1]. Bacteria belonging to the family Enterobacteriaceae include important pathogens that are ubiquitous in nature. The ability of Enterobacteriaceae to acquire mobile genetic elements carrying antibiotic resistance through horizontal transfer of genes has enabled this group to be the most successful in acquisition of resistance to multiple antibiotics, including the most effective next generation carbapenems [2].

In recent years there has been a tremendous increase in the incidence of critical infections in which the etiological agent is MDR gram-negative bacteria, in particular cephalosporin- and carbapenem-resistant Enterobacteriaceae. The ability to produce extended spectrum $\beta$-lactamases (ESBL) allows bacteria to be resistant to most beta-lactam antibiotics, including cephalosporin [3], an important drug of choice for treating both gram-positive and gram-negative bacterial infections. Widespread resistance to newer generations of cephalosporins is attributed largely to the spread of CTX-M type extended-spectrum $\beta$-lactamases (ESBLs) in gram-negative bacteria, especially in Escherichia coli. As a result, the rapid global dissemination of the ESBL-producing E. coli is an emerging public-health concern [4]. For ESBL and Ampicillinase C $(\mathrm{AmpC})$ producers, carbapenems are the drugs of choice [5]. But dissemination of plasmid-mediated carbapenemases such as Klebsiella pneumoniae Carbapenemase (KPC) and metallo-lactamases, e.g. VIM, NDM-1 and IMP in carbapenem resistant Enterobacteriaceae (CRE) [6] left no drug to control them except for the last resort antibiotics, like colistin [7].

Colistin (also known as polymyxin E) is a cationic polypeptide antibiotic that interacts with the outer membrane of the gram-negative bacteria [8]. Despite colistin once being avoided due to its nephro- and neurotoxicity [9], this drug has now become a last-resort antimicrobial agent for treating life-threatening infections caused by MDR gram-negative bacteria. However, in November 2015, the first plasmid borne colistin resistance gene $m c r-1$, encoding a phosphoethanolamine transferase, was detected in livestock and raw meat samples as well as humans in China [10]. A recent study in Bangladesh reported $m c r-1$ carrying $E$. coli in an urban sludge sample collected from Dhaka city [11]. Although little is known about the use of colistin in the clinical management of infectious diseases, this antibiotic has been widely used in the poultry industries of Bangladesh [12]. A recent study has reported $E$. coli carrying $m c r-3$ from poultry in Moymonsingh, Bangladesh [13]. This cross-sectional study reported here was carried out in Dhaka city with the aim to understand the distribution of colistin resistant E. coli in street food and drink, water, hand rinse samples of street food-drink vendors, and stool from healthy humans.

\section{Materials and method Sample collection}

To investigate the occurrence of colistin resistant bacteria, a total of 65 samples comprising healthy human stool $(n=20)$, street food and drink $[n=20$; mixed fruit juice $(n=3)$, sugarcane juice $(n=2)$, Velpuri (a widely liked food item; $n=3)$, sliced guava mixed with pickles $(n=1)$, sliced pineapple mixed with pickles $(n=3)$, Peas cooked with spices $(n=3)$, and sliced cucumber $(n=5)]$, hand rinse samples of street food handlers $(n=15)$, and surface water $(n=10)$ were collected randomly from Dhaka city during June 2018. Human stools for healthy individuals were collected aseptically in stool collection cups and placed immediately in Cary-Blair media and transported to laboratory maintaining cold-chain. The water samples were collected using sterile $500 \mathrm{~mL}$ dark Nalgene bottles (Nalgene Nunc International, St. Louis, Mo.) and food samples were collected in $120 \mathrm{~mL}$ Whirlpak bag (NASCO WHIRL-PAK ${ }^{\circledR}$, USA). For collection of hand rinse samples, street food handlers were asked to insert and wash their hands in 800-ml Whirl-Pak bag (NASCO WHIRLPAK $^{\circledR}$, USA) containing $250 \mathrm{ml}$ of sterile phosphate buffered saline. All samples were transported to the icddr, b laboratory in an insulated cool box (with ice packs).

\section{Isolation of Escherichia coli}

The isolation of $E$. coli from all samples were performed using MacConkey agar (BD Difco, USA). Stool and juice samples were directly inoculated on MacConkey agar, while food samples were homogenized and diluted in PBS before inoculation on agar plates. For hand rinse and surface water samples, water was filtered through $0.22 \mu \mathrm{m}$ filter papers and then the membrane filters were placed on MacConkey agar plate. The inoculated plates were incubated overnight at $37{ }^{\circ} \mathrm{C}$. Bright pink lactosefermenting colonies were selected as presumptive E. coli, which were grown on eosin methylene blue (EMB) agar to examine for the production of green colonies with a metallic sheen, a characteristic of important diagnostic implication for the bacterium. One presumptive colony per sample was selected at random, and subjected to biochemical confirmation with API 20 E (BioMerieux, France).

\section{Detection of colistin resistance $m c r-1$ gene}

Bacterial DNA was obtained from all isolates by the boiling method [14]. All E. coli strains were examined for the presence of $m c r-1$ gene by polymerase chain reaction (PCR) using primers as described elsewhere [10]. The primer sequences and corresponding annealing 
temperatures used in all PCR reactions in this study are listed in Table 1.

\section{Sequencing of $m c r-1$ gene}

Amplified fragment of $m c r-1$ was sequenced using an ABI PRISM Big Dye Terminator Cycle Sequencing Reaction kit (Applied Biosystems) on an ABI PRISM 310 automated sequencer (Applied Biosystems). The raw sequences were subjected to sequence analysis software (Chromas), the sequences were then searched for homology using Basic Local Alignment Search Tool (BLAST). The partial sequences of the gene were submitted to GenBank (Accession Numbers: MN337021, MN337022, MN337023, MN337024, and MN337025).

\section{Determination of minimum inhibitory concentration (MIC)} of colistin

The $m c r-1$ positive strains were tested for their response to colistin by measuring the MIC by E-test (BioMerieux). The results were interpreted according to European
Committee on Antimicrobial Susceptibility Testing (EUCAST) breakpoints [15]. Although broth microdilution assay is recommended by EUCAST for determining MIC, several studies have found a congruous correlation between the E-test and reference techniques [16-18].

\section{Antimicrobial susceptibility tests}

Colistin resistant strains were tested for their susceptibility to other antimicrobials following the disc diffusion method as described by Bauer et al. [19] using commercially available antibiotic discs. Eighteen commonly used antibiotics (Oxoid, UK) tested in this study include: ceftriaxone (CRO $30 \mu \mathrm{g})$, cephalothin (KF $30 \mu \mathrm{g})$, cefipime (FEP $30 \mu \mathrm{g}$ ), cefixime (CFM $5 \mu \mathrm{g}$ ), fosfomycin (FOS $50 \mu \mathrm{g}$ ), mecillinam ( MEL $25 \mu \mathrm{g}$ ), tetracycline (TE $30 \mu \mathrm{g}$ ), sulphamethoxazole-trimethoprium (SXT $25 \mu \mathrm{g}$ ), levofloxacin (LEV $5 \mu \mathrm{g}$ ), erythromycin (E $15 \mu \mathrm{g})$, azithromycin (AZM $15 \mu \mathrm{g}$ ), imipenem (IPM $10 \mu \mathrm{g}$ ), ampicillin (AMP $10 \mu \mathrm{g}$ ), nalidixic Acid (NA $30 \mu \mathrm{g}$ ), ciprofloxacin (CIP $5 \mu \mathrm{g})$, gentamicin (CN $10 \mu \mathrm{g})$, chloramphenicol (C

Table 1 PCR primers used in this study

\begin{tabular}{|c|c|c|c|c|}
\hline Target gene & Primer & Sequence & Amplicon size (bp) & References \\
\hline \multirow[t]{2}{*}{ mor1 } & CLR5F & CGGTCAGTCCGTTTGTTC & 309 & {$[10]$} \\
\hline & CLR5R & CTTGGTCGGTCTGTA GGG & & \\
\hline \multirow[t]{2}{*}{$\mathrm{LT}$} & LT 450F & GGCGACAGATTATACCGTGC & 450 & {$[21]$} \\
\hline & LT 450R & CGGTCTCTATATTCCCTGT & & \\
\hline \multirow[t]{2}{*}{$S T p$} & STp186F & TCTGTATTATCTTTCCCCTC & 186 & {$[22]$} \\
\hline & STp 186R & ATAACATCCAGCACAGGC & & \\
\hline \multirow[t]{2}{*}{ STh } & STh5f & TCACCTTTCCCTCAGGAT & 160 & {$[23]$} \\
\hline & STh6r & TACAAGCAGGATTACAACAC & & \\
\hline \multirow[t]{2}{*}{ pCVD432 } & EAEC1 & CTGGCGAAAGACTGTATCAT & 630 & {$[24]$} \\
\hline & EAEC2 & CAATGTATAGAAATCCGCTGTT & & \\
\hline \multirow[t]{2}{*}{ bla $a_{\text {CTX-M-15 }}$} & CTX-M-15F & CACACGTGGAATTTAGGGACT & 996 & {$[25]$} \\
\hline & CTX-M-15R & GCCGTCTAAGGCGATAAACA & & \\
\hline \multirow[t]{2}{*}{$b l a_{\mathrm{CTX}-\mathrm{M}-2}$} & $\mathrm{CTXM} 2 \mathrm{~F}$ & CGGYGCTTAAACAGAGCGAG & 891 & {$[26]$} \\
\hline & CTXM2R & CCATGAATAAGCAGCTGATTGCCC & & \\
\hline \multirow[t]{2}{*}{$b l a_{\mathrm{CTX}-\mathrm{M}-8}$} & CTXM8F & ACGCTCAACACCGCGATC & 490 & {$[26]$} \\
\hline & CTXM8R & CGTGGGTTCTCGGGGATAA & & \\
\hline \multirow[t]{2}{*}{$b l a_{C T X-M-9}$} & CTXM9F & GATTGACCGTATTGGGAGTTT & 947 & {$[26]$} \\
\hline & CTXM9R & CGGCTGGGTAAAATAGGTCA & & \\
\hline \multirow[t]{2}{*}{$b l a_{\mathrm{TEM}}$} & TEM-R & ACGCTCAGTGGAACGAAAAC & 1150 & {$[27]$} \\
\hline & TEM-F & ATTCTTGAAGACGAAAGGGC & & \\
\hline \multirow[t]{2}{*}{$b l a_{\mathrm{NDM} 1}$} & NDM-1F & GGTTTGGCGATCTGGTTTTC & 621 & {$[28]$} \\
\hline & $\mathrm{NDM}-1 \mathrm{R}$ & CGGAATGGCTCATCACGATC & & \\
\hline \multirow[t]{2}{*}{$b l a_{\mathrm{OXA}-48}$} & OXA-F & GCGTGGTTAAGGATGAACAC & 438 & {$[29]$} \\
\hline & OXA-R & CATCAAGTTCAACCCAACCG & & \\
\hline \multirow[t]{2}{*}{$b l a_{\mathrm{CMY}-2}$} & CMY-2-R & CCCGTTTTATGCACCCATGA & 870 & {$[30]$} \\
\hline & CMY-2-F & TGGCCGTTGCCGTTATCTAC & & \\
\hline \multirow[t]{2}{*}{ mphA } & mphA-F & GTGAGGAGGAGCTTCGCGAG & 403 & {$[31]$} \\
\hline & mphA-R & TGCCGCAGGACTCGGAGGTC & & \\
\hline
\end{tabular}


$30 \mu \mathrm{g}$ ), and aztreonam (ATM $30 \mu \mathrm{g}$ ). The resistance or susceptibility profiles of the isolates were determined by measuring the inhibitory zone and comparing it with an interpretative chart to determine sensitivity to the antibiotics according to Clinical and Laboratory Standards Institute guideline [20]. E. coli ATCC 25922 was used as a positive control.

\section{Detection of virulence gene}

Colistin resistant $E$. coli isolates were tested for the presence of genes for ETEC-specific heat-labile toxin $(l t)$ and heat stable toxin $(S T p, S T h)$, EAEC virulence plasmid pCVD432 by PCR.

\section{Detection of genes associated with ESBL carbapenem and macrolide resistance}

The colistin resistant E. coli strains were targeted to detect ESBL genes $\left(b l a_{\mathrm{CTX}-\mathrm{M}-15}, b l a_{\mathrm{CTX}-\mathrm{M}-2 \text {-group }}, b l a_{\mathrm{CTX}-}\right.$ M-8-group, $b l a_{\text {CTX-M-9-group, }}$ bla $\left.{ }_{\text {TEM }}\right)$, carbapenemase genes $\left(b_{l} a_{\mathrm{NDM}-1} b l a_{\mathrm{OXA}-48}, b l a_{\mathrm{CMY}-2}\right)$, and macrolide resistance gene $(m p h A)$ by PCR.

\section{Pulsed-field gel electrophoresis (PFGE)}

$m c r-1^{+}$E. coli strains were analyzed using pulsed-field gel electrophoresis (PFGE) according to standard protocols [32]. The fingerprint patterns were typed according to banding similarity and dissimilarity, using the dice similarity coefficient and unweighted-pair group method employing average linkage (UPGMA) clustering, as recommended by the manufacturer. The results were graphically represented as dendrograms.

\section{Results and discussion}

A total $65 \mathrm{E}$. coli were isolated by culture methods from street food $(n=20)$, hand rinse $(n=15)$, surface water $(n=10)$, and healthy human stool $(n=20)$. The genomic DNA of these strains were subjected to PCR using specific primers for the colistin resistance gene $m c r-1$ [10]. Of the 65 E. coli strains tested, 13 (20\%) (Street food; 4, hand rinse; 2 , surface water; 4 , and healthy human gut; 3) carried a $309 \mathrm{bp}$ amplicon specific for the $m c r-1$ gene (Table 2). The 309 bp fragments of $m c r-1$ from five representative $E$. coli strains from healthy human stool $(\mathrm{n}=2)$, water $(\mathrm{n}=1)$, hand rinse $(\mathrm{n}=1)$, and street food $(\mathrm{n}=1)$ were subjected to nucleotide sequencing (Genbank Accession No. MN337021, MN337022, MN337023, MN337024, and MN337025). Although it was not possible in this study to cover the full-length sequence of the gene, BLAST homology search demonstrated the nucleotide sequences to be identical to that of the corresponding $m c r-1$ portion reported earlier from $E$. coli strains (Genbank Accession No. KP347127, NG056412, CP015913, KY770023, and KY550358). These previously reported sequences were found in E.coli isolated from animal and water sources of China, Japan, USA, Brazil and South America. E. coli carrying $m c r-1$ has been reported in recent years from urban sludge samples from Bangladesh [11]. The data in the present study show how rapidly the colistin resistant $E$. coli carrying $m c r-1$ has been disseminating, as those were found from street foods, hand rinse samples of the street food vendors, and healthy human gut in Dhaka, a densely populated city of Bangladesh. Although the study was limited to Dhaka, the results may be indicative of the prevalence and spread of the colistin resistant $E$. coli throughout Bangladesh.

Table 2 MIC value and drug resistance pattern of colistin resistant $m c r-1$ carrying $E$. coli $(n=13)$ strains

\begin{tabular}{|c|c|c|c|c|}
\hline Source & No. of isolates & $m c r-1$ & $\begin{array}{l}\text { MIC of colistin }(\mu \mathrm{g} / \\
\mathrm{ml})\end{array}$ & Resistance pattern \\
\hline Street drink (sugarcane juice) & 1 & + & 4 & $\begin{array}{l}\text { KF, CFM, CRO, TE, SXT, LEV, E, AZM, AMP, } \\
\text { NA, CN, CIP, ATM }\end{array}$ \\
\hline Street drink (sugarcane juice) & 1 & + & 4 & KF, TE, SXT, LEV, E, AMP, NA, CIP.CN \\
\hline Street drink (mixed fruit juice) & 1 & + & 3 & TE, SXT, E, AMP, CN \\
\hline Street drink (mixed fruit juice) & 1 & + & 6 & $\mathrm{KF}, \mathrm{TE}, \mathrm{SXT}, \mathrm{E}, \mathrm{AZM}, \mathrm{AMP}, \mathrm{CN}, \mathrm{NA}$ \\
\hline Hand rinse & 1 & + & 4 & TE, SXT, E, AMP, NA \\
\hline Hand rinse & 1 & + & 2 & KF, TE, SXT, LEV, E, AMP, NA, CIP, C \\
\hline Surface water & 1 & + & 3 & TE, SXT, E, AMP, NA \\
\hline Surface water & 1 & + & 4 & TE, SXT, AZM, E, AMP, NA \\
\hline Surface water & 1 & + & 4 & KF, TE, SXT, LEV, E, AZM, AMP, NA, CN, CIP, C \\
\hline Surface water & 1 & + & 4 & $\mathrm{KF}, \mathrm{TE}, \mathrm{AMP}$ \\
\hline Healthy human stool & 2 & + & 4 & KF, TE, SXT, LEV, E, AZM, AMP, NA, CIP, CN \\
\hline Healthy human stool & 1 & + & 3 & KF, TE, SXT, E, AMP, CN \\
\hline
\end{tabular}

CFM cefixime, $K F$ cephalothin, CRO ceftriaxone, TE tetracycline, SXT sulphamethoxazole/trimethoprium, LEV levofloxacin, E erythromycin, $A Z M$ azithromycin, $A M P$ ampicillin, NA nalidixic acid, CN gentamicin, CIP ciprofloxacin, ATM aztreonam, C chloramphenicol 


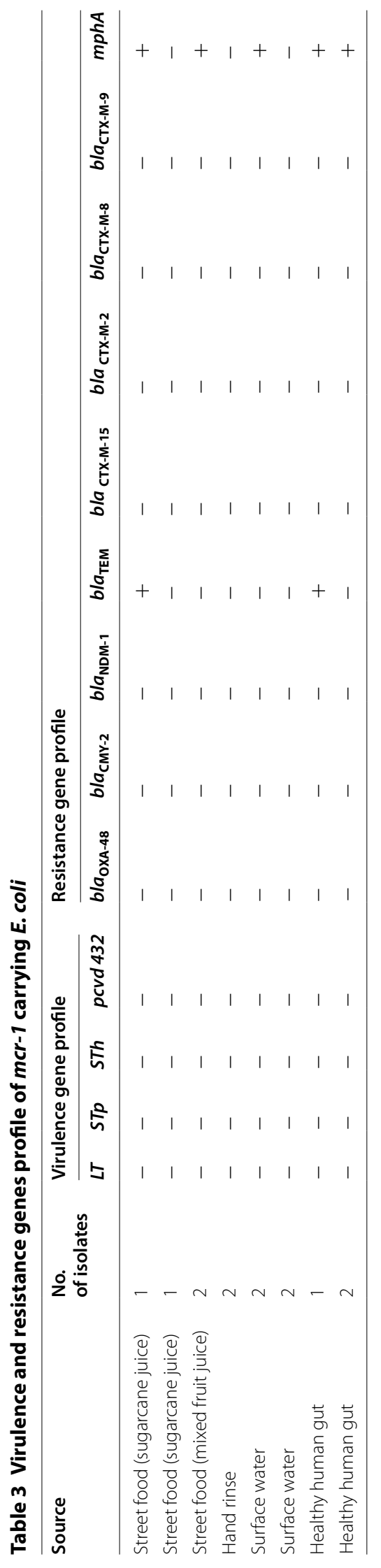



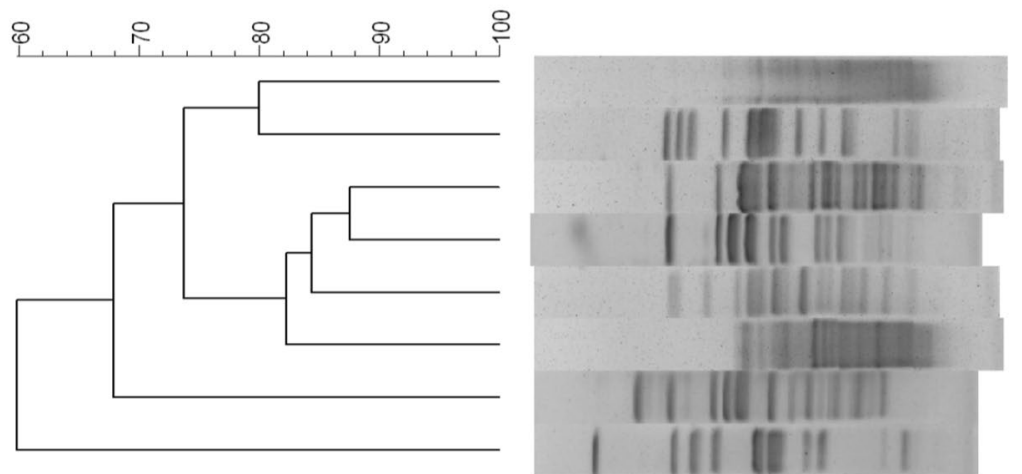

$\begin{array}{ll}\text { Source } & \text { Year } \\ \text { Stool } & 2018 \\ \text { Water } & 2018 \\ \text { Hand Rinse } & 2018 \\ \text { Street Food } & 2018 \\ \text { Water } & 2018 \\ \text { Street Food } & 2018 \\ \text { Street Food } & 2018 \\ \text { Hand Rinse } & 2018\end{array}$

Fig. 1 Dendrogram showing genomic relatedness of mcr-1 carrying E. coli strains. Pulsed-field gel electrophoresis (PFGE) patterns of Xbal-digested genomic DNA of representative mcr-1 carrying E. coli strains isolated from healthy human gut, water, street food and hand rinse of street food vendors. The dendrogram was prepared by the BioNeumeric software (Applied Maths) using dice similarity coefficient and unweighted-pair group method employing average linkage of the PFGE images of the E. coli strains. The scale bar at the top (left) indicates similarity coefficient (\%).

Escherichia coli strains carrying $m c r-1$ were found to be resistant to colistin in the present study. The MIC value was determined to range from 2 to $6 \mu \mathrm{g} / \mathrm{ml}$. Using the Kirby-Bauer disk diffusion assay, we showed that these colistin resistant $E$. coli strains were MDR with resistance varying from 3 to 13 different antibiotics. Among the 13 mcr-1 carrying E. coli strains, 100\% (13/13) were resistant to tetracycline and ampicillin, 92\% (12/13) resistant to erythromycin and sulphamethoxazole-trimethoprium, $77 \%(10 / 13)$ resistant to nalidixic acid, 69\% (9/13) resistant to cephalothin, $62 \%(8 / 13)$ resistant to gentamycin, $46 \%(6 / 13)$ resistant to levofloxacin, azithromycin and ciprofloxacin, $15 \%(2 / 13)$ resistant to chloramphenicol, and $8 \%(1 / 13)$ resistant to cefixime, ceftriaxone and aztreonam. All of the $m c r-1$ carrying E. coli strains were sensitive to fosfomycin, mecillinam, imipenem, and cefipime. Only one strain was resistant to 3rd generation cephalosporins (cefixime and ceftriaxone). The widespread occurrence of colistin resistant MDR E. coli is alarming for a densely populated country like Bangladesh where morbidity and mortality due to infectious diseases are prevalent $[12,33]$. Transmission control of colistin resistant bacteria warrant urgent attention, although further studies would be required to comprehend the transmission from community to clinical settings.

We tested all of the $m c r-1$ positive $E$. coli strains for the presence of other important antimicrobial resistance marker genes. Of the $13 \mathrm{mcr}-1$ carrying E. coli strains, only two isolated from street food and healthy human gut harbored the ESBL gene bla $a_{T E M}$. Also, eight E. coli strains isolated from street food $(n=3)$, surface water $(\mathrm{n}=2)$ and healthy human gut $(\mathrm{n}=3)$ had the macrolide resistance gene $m p h A$, which reflects the higher percentage of erythromycin and azithromycin resistance within the isolates (Table 3). Although we have not tested the strains for plasmid carriage, ESBL and $m c r-1$ genes can co-exist on the same plasmid and therefore could facilitate dissemination of colistin resistance [34]. The E. coli strains carrying $m c r-1$ were heterogenous genetically, as confirmed by PFGE (Fig. 1), suggesting horizontal transmission of the antimicrobial resistance genes. None of the $m c r-1$ carrying $E$. coli strains in the present study are believed to be pathogenic as they did not carry any of the virulence and related genes namely $L T, S T p, S T h$ and pcvd432 plasmid. Nonetheless, the occurrence of colistin resistant bacteria in the human gut was important as they could serve as a reservoir for future transfer to pathogenic strains.

\section{Conclusion}

The usefulness of colistin, a last-resort antibiotic for the treatment of MDR gram-negative bacterial infections, is being compromised as shown by the recent identification of the mobile colistin resistance gene, $m c r-1$ [10]. The $m c r-1$ gene has spread to most continents, and has been detected in various bacterial isolates from animals, human and the environment, including E. coli, Klebsiella pneumoniae, Enterobacter cloacae and Enterobacter aerogenes [35]. In Bangladesh, colistin resistant E. coli carrying $m c r-1$ was reported earlier from urban sludge samples [11]. Here in this study, colistin resistant E. coli carrying $m c r-1$ gene was found from water, street food, 
hand rinse samples of street food vendors, and healthy human gut samples in Bangladesh. This is alarming and sheds light on the potential health risk that colistin resistant $E$. coli could pose to millions of people in Bangladesh as colistin is a last resort antibiotic for the treatment of MDR gram-negative bacterial infections.

\section{Acknowledgements}

International Centre for Diarrheal Disease Research, Bangladesh acknowledges the following donors: the Governments of Bangladesh, Canada, Sweden and United Kingdom for providing core/unrestricted support.

\section{Authors' contributions}

FTJ and MA participated in the conception and design of the study. FTJ, JT, IB, SRB, FTJ and MS performed the laboratory work. FT and MA analyzed the data and wrote the manuscript. CMG, AC, KDS, and NA contributed to the analysis and helped in writing the manuscript. All authors read and approved the final manuscript.

\section{Funding}

This research study was supported jointly by International Centre for Diarrheal Disease Research, Bangladesh, NIH Grant 1R01Al39129-01 and the National Institutes of Infectious Diseases (NIID), Japan.

\section{Availability of data and materials}

Sequence data that support the findings of this study have been deposited in GenBank with the primary accession codes MN337021, MN337022, MN337023, MN337024, and MN337025.

\section{Ethics approval and consent to participate}

Ethical approval and consent to participate was obtained from the ethical committee of International Center for Diarrheal Disease Research, Bangladesh (icddr, b).

\section{Consent for publication}

Yes.

\section{Competing interests}

The authors declare that they have no competing interests.

\section{Author details}

${ }^{1}$ Infectious Diseases Division (IDD), International Centre for Diarrheal Disease Research (icddr,b), 68, Shaheed Tajuddin Ahmed Sharani, Dhaka 1212, Bangladesh. ${ }^{2}$ Johns Hopkins Bloomberg School of Public Health, Baltimore, USA.

${ }^{3}$ Tufts University, Medford, USA. ${ }^{4}$ University of California, Berkeley, USA.

Received: 16 September 2019 Accepted: 9 January 2020

Published online: 27 January 2020

\section{References}

1. Aslam B, Wang W, Arshad MI, Khurshid M, Muzammil S, Rasool MH, Nisar MA, Alvi RF, Aslam MA, Qamar MU, Salamat MK. Antibiotic resistance: a rundown of a global crisis. Infect Drug Resist. 2018;11:1645.

2. Lerminiaux NA, Cameron AD. Horizontal transfer of antibiotic resistance genes in clinical environments. Can J Microbiol. 2018;65(1):34-44.

3. Smet A, Martel A, Persoons D, Dewulf J, Heyndrickx M, Catry B, Herman L, Haesebrouck F, Butaye P. Diversity of extended-spectrum $\beta$-lactamases and class $C \beta$-lactamases among cloacal Escherichia coli isolates in Belgian broiler farms. Antimicrob Agents Chemother. 2008;52(4):1238-43.

4. Pitout JD, Laupland KB. Extended-spectrum $\beta$-lactamase-producing Enterobacteriaceae: an emerging public-health concern. Lancet Infect Dis. 2008;8(3):159-66.

5. Rodríguez-Baño J, Gutiérrez-Gutiérrez B, Machuca I, Pascual A. Treatment of infections caused by extended-spectrum-beta-lactamase-, AmpC-, and carbapenemase-producing Enterobacteriaceae. Clin Microbiol Rev. 2018;31(2):e00079-e117.
6. Pfeifer Y, Cullik A, Witte W. Resistance to cephalosporins and carbapenems in gram-negative bacterial pathogens. Int I Med Microbiol. 2010;300(6):371-9.

7. Nation RL, Li J. Colistin in the 21 st century. Current Opin Infect Dis. 2009;22(6):535-43. https://doi.org/10.1097/QCO.0b013e328332e672.

8. Baron S, Hadjadj L, Rolain JM, Olaitan AO. Molecular mechanisms of polymyxin resistance: knowns and unknowns. Int J Antimicrob Agents. 2016;48(6):583-91.

9. Koch-Weser JA, Sidel VW, Federman EB, Kanarek P, Finer DC, Eaton AE. Adverse effects of sodium colistimethate: manifestations and specific reaction rates during 317 courses of therapy. Ann Intern Med. 1970;72(6):857-68.

10. Liu YY, Wang Y, Walsh TR, Yi LX, Zhang R, Spencer J, Doi Y, Tian G, Dong B, Huang $X$, Yu LF. Emergence of plasmid-mediated colistin resistance mechanism MCR-1 in animals and human beings in China: a microbiological and molecular biological study. Lancet Infect Dis. 2016;16(2):161-8.

11. Islam A, Rahman Z, Monira S, Rahman MA, Camilli A, George CM, Ahmed N, Alam M. Colistin resistant Escherichia coli carrying mcr-1 in urban sludge samples: Dhaka, Bangladesh. Gut Pathog. 2017;9(1):77.

12. Islam KS, Shiraj-Um-Mahmuda S, Hazzaz-Bin-Kabir M. Antibiotic usage patterns in selected broiler farms of Bangladesh and their public health implications. J Public Health Dev Countries. 2016;2(3):276-84.

13. Sobur MA, levy S, Haque ZF, Nahar A, Zaman SB, Rahman MT. Emergence of colistin-resistant Escherichia coli in poultry, house flies, and pond water in Mymensingh, Bangladesh. J Adv Vet Anim Res. 2019;6(1):50-3.

14. Šeputienè V, Povilonis J, Ružauskas M, Pavilonis A, Sužiedèlienẻ E. Prevalence of trimethoprim resistance genes in Escherichia coli isolates of human and animal origin in Lithuania. J Med Microbiol. 2010;59(3):315-22.

15. European Committee on Antimicrobial Susceptibility Testing. Breakpoint tables for interpretation of MICs and zone diameters: version 6.0. (2016). https://www.eucast.org/feadmin/src/media/PDFs/EUCAST_fes/ Breakpoint_tables/v_6.0_Breakpoint_table.pdfAccessed 15 Mar 2016

16. Behera B, Mathur P, Das A, Kapil A, Gupta B, Bhoi S, Farooque K, Sharma $\checkmark$, Misra MC. Evaluation of susceptibility testing methods for polymyxin. Int J Infect Dis. 2010;14(7):e596-601.

17. Lo-Ten-Foe JR, de Smet AM, Diederen BM, Kluytmans JA, van Keulen PH. Comparative evaluation of the VITEK 2, disk diffusion, Etest, broth microdilution, and agar dilution susceptibility testing methods for colistin in clinical isolates, including heteroresistant Enterobacter cloacae and Acinetobacter baumannii strains. Antimicrob Agents Chemother. 2007;51(10):3726-30.

18. Maalej SM, Meziou MR, Rhimi FM, Hammami A. Comparison of disc diffusion, Etest and agar dilution for susceptibility testing of colistin against Enterobacteriaceae. Lett Appl Microbiol. 2011;53(5):546-51.

19. Bauer AW, Kirby WM, Sherris JC, Turck M. Antibiotic susceptibility testing by a standardized single disk method. Am J Clin Pathol. 1966;45(4_ts):493-6.

20. CLSI. Performance Standards for Antimicrobial Susceptibility Testing. 26th ed. CLSI supplement M100S. Wayne, PA: Clinical and Laboratory Standards Institute; 2016.

21. Aranda KR, Fagundes-Neto U, Scaletsky IC. Evaluation of multiplex PCRs for diagnosis of infection with diarrheagenic Escherichia coli and Shigella spp. J Clin Microbiol. 2004;42(12):5849-53.

22. Schultsz C, Pool GJ, Van Ketel R, De Wever B, Speelman P, Dankert J. Detection of enterotoxigenic Escherichia coli in stool samples by using nonradioactively labeled oligonucleotide DNA probes and PCR. J Clin Microbiol. 1994;32(10):2393-7.

23. Bölin I, Wiklund G, Qadri F, Torres O, Bourgeois AL, Savarino S, Svennerholm AM. Enterotoxigenic Escherichia coli with STh and STp genotypes is associated with diarrhea both in children in areas of endemicity and in travelers. J Clin Microbiol. 2006;44(11):3872-7.

24. Schmidt H, Knop C, Franke S, Aleksic S, Heesemann J, Karch H. Development of PCR for screening of enteroaggregative Escherichia coli. J Clin Microbiol. 1995;33(3):701-5.

25. Sidjabat HE, Paterson DL, Adams-Haduch JM, Ewan L, Pasculle AW, Muto CA, Tian GB, Doi Y. Molecular epidemiology of CTX-M-producing Escherichia coli isolates at a tertiary medical center in western Pennsylvania. Antimicrob Agents Chemother. 2009;53(11):4733-9. 
26. Ryoo NH, Kim EC, Hong SG, Park YJ, Lee K, Bae IK, Song EH, Jeong SH. Dissemination of SHV-12 and CTX-M-type extended-spectrum $\beta$-lactamases among clinical isolates of Escherichia coli and Klebsiella pneumoniae and emergence of GES-3 in Korea. J Antimicrob Chemother. 2005;56(4):698-702.

27. Sáenz Y, Brinas L, Domínguez E, Ruiz J, Zarazaga M, Vila J, Torres C. Mechanisms of resistance in multiple-antibiotic-resistant Escherichia coli strains of human, animal, and food origins. Antimicrob Agents Chemother. 2004:48(10):3996-4001.

28. Sheikh AF, Rostami S, Jolodar A, Tabatabaiefar MA, Khorvash F, Saki A, Shoja S, Sheikhi R. Detection of metallo-beta lactamases among carbapenem-resistant Pseudomonas aeruginosa. Jundishapur J Microbiol. 2014;7(11):e12289.

29. Abdulla AA, Al-Dahmoshi HO, Abed TA, Muttaleb WH. Characterization of multidrug resistant carbapenemases-producing Escherichia coli and Klebsiella pneumoniae isolates from urinary tract infection. J Chem Pharm Sci. 2016;9(3):1116-20.

30. Torkan S, Khamesipour F, Anyanwu MU. Detection of virulence and antibacterial resistance genes in Salmonella isolates from diarrhoeic dogs in Iran. Rev Med Vet. 2015;1(166):221-8.

31. Nguyen MC, Woerther PL, Bouvet M, Andremont A, Leclercq R, Canu A. Escherichia coli as reservoir for macrolide resistance genes. Emerg Infect Dis. 2009;15(10):1648
32. Ribot EM, Fair MA, Gautom R, Cameron DN, Hunter SB, Swaminathan B, Barrett TJ. Standardization of pulsed-field gel electrophoresis protocols for the subtyping of Escherichia coli O157: H7, Salmonella, and Shigella for PulseNet. Foodbourne Pathog Dis. 2006;3(1):59-67.

33. Rahman Z, Islam A, Rashid MU, Johura FT, Monira S, Watanabe H, Ahmed $\mathrm{N}$, Camilli A, Alam M. Existence of a novel gepA variant in quinolone resistant Escherichia coli from aquatic habitats of Bangladesh. Gut Pathog. 2017:9(1):58.

34. Dandachi I, Chabou S, Daoud Z, Rolain JM. Prevalence and Emergence of extended-spectrum cephalosporin-, carbapenem-and colistin-resistant gram negative bacteria of animal origin in the Mediterranean Basin. Front Microbiol. 2018; https://doi.org/10.3389/fmicb.2018.02299.

35. Skov RL, Monnet DL. Plasmid-mediated colistin resistance (mcr-1 gene): three months later, the story unfolds. Eurosurveillance. 2016;21(9):30155.

\section{Publisher's Note}

Springer Nature remains neutral with regard to jurisdictional claims in published maps and institutional affiliations.
Ready to submit your research? Choose BMC and benefit from:

- fast, convenient online submission

- thorough peer review by experienced researchers in your field

- rapid publication on acceptance

- support for research data, including large and complex data types

- gold Open Access which fosters wider collaboration and increased citations

- maximum visibility for your research: over $100 \mathrm{M}$ website views per year

At BMC, research is always in progress.

Learn more biomedcentral.com/submissions 